\title{
PERSEPSI PRAKTISI DAN PENGGUNA JASA AKUNTAN FORENSIK TERHADAP KEAHLIAN AKUNTAN FORENSIK
}

\begin{abstract}
This study aims to determine the perceptions of practitioners and users of forensic accountants about the expertise of forensic accountants. The population of this research are BPK and BPKP as practitioners of forensic accountant and prosecutor and judge as user of forensic accountant service in Semarang and Yogyakarta city. Population in this research amounted to 403. Sampling was done by technique of Purposive Sampling and obtained sample counted 253 respondents. This study used ANOVA test and if the result is significant continued with Tukey test. The results show that there is no difference in the perceptions of practitioners and users of forensic accounting services about the skills of a forensic accountant. Likewise, this study proves that practitioners and users of forensic accounting services are no different. The study also found that practitioners and users of forensic accountants agree differently on the importance of deductive analysis skills, critical thinking skills, unstructured problem solving, analytical skills, oral communication, legal knowledge and tranquility. The implications of this study are expected in the preparation of forensic accountant curricula can refer to the results of this study
\end{abstract}

Kata Kunci : Akuntan Forensik, Praktisi, Pengguna Jasa, Jaksa, Hakim, BPK, BPKP

\section{PENDAHULUAN}

Akuntan forensik berperan untuk membuktikan tentang ada dan tidaknya unsur korupsi. Menurut Hopwood et al. (2008) dalam Iprianto (2009) akuntan forensik adalah akuntan yang menjalankan kegiatan evaluasi dan penyelidikan, dari hasil tersebut dapat digunakan di dalam pengadilan hukum. Dalam menjalankan tugasnya seorang akuntan forensik mempraktekkan keahlian khusus dalam bidang akuntansi, auditing, keuangan, metode-metode kuantitatif, bidang-bidang tertentu dalam hukum, penelitian, dan keterampilan investigatif dalam mengumpulkan bukti, menganalisis, dan mengevaluasi materi bukti dan menginterpretasi serta mengkomunikasikan hasil dari temuan tersebut (Iprianto, 2009). Kebutuhan akuntan forensik di Indonesia sendiri terus meningkat, seiring dengan maraknya kasus korupsi yang terungkap ke kalangan publik.

Pihak yang sering melakukan peran akuntan forensik dalam mengungkap kasus korupsi di institusi pemerintahan Indonesia adalah pihak BPK (Badan Pemeriksa Keuangan) dan BPKP (Badan Pengawasan Keuangan dan Pembangunan). Peran BPK dan BPKP sebagai saksi ahli dalam persidangan pun sudah terlihat dalam beberapa kasus di Indonesia. Diantaranya yaitu Muhammad Yusuf, Ahli dari Badan Pengawasan Keuangan dan Pembangunan (BPKP) telah menjadi saksi ahli dalam sidang lanjutan kasus dugaan korupsi Bank Mandiri yang digelar di Pengadilan Negeri Jakarta Selatan tanggal 22 Desember 2005 (Wikipedia Indonesia). Tuanakota (2009) juga menyebutkan tentang peran Ahli BPK sebagai saksi ahli dalam persidangan. Novi Gregori Antonius menjadi saksi ahli dalam kasus aliran dana Yayasan Pengembangan Perbankan Indonesia 
(YPPI)/bank Indonesia (BI) dengan terdakwa mantan Gubernur BI, Burhanuddin Abdullah (Bisnis Indonesia, 2011).

Tuanakota (2009) menyatakan bahwa perguruan tinggi (seperti Sekolah Tinggi Akuntansi Negara serta Fakultas Ekonomi/Jurusan Akuntansi dan Fakultas Hukum) berpotensi untuk melahirkan Ahli yang memberikan keterangan Ahli di persidangan. Pengertian Ahli di sini adalah seorang akuntan forensik. Peran akuntan forensik sebagai saksi ahli di persidangan adalah memberikan penjelasan tentang adanya potensi kerugian keuangan negara. Jadi selain berhubungan dengan lingkungan praktek di lapangan, akuntansi forensik juga berhubungan dengan lingkungan praktek di persidangan. Harris and Brown (2000) menyatakan bahwa akuntan forensik biasanya sudah terbiasa dengan hukum kriminal, prosedur dan harapan pengadilan. Messmer (2004) sendiri menyatakan bahwa akuntan forensik yang sukses harus mempunyai kemampuan analitis, keahlian komunikasi verbal dan tertulis, berpikiran kreatif dan business sense. Ramaswamy (2005) menyatakan bahwa akuntan forensik harus mampu mengungkap kecurangan keuangan, kemampuan berpikir kritis dan memahami skema kecurangan.

Singleton et al. (2006) menyatakan bahwa akuntan forensik harus mampu mengungkap kecurangan dengan informasi yang terbatas, mampu mengidentifikasi isu keuangan, mengetahui tehnik investigatif, pengetahuan tentang bukti, menginterpretasikan informasi keuangan, mempresentasikan temuan, serta memiliki keahlian dan mental investigatif. Lindquist et al. (2006) sendiri menyebutkan beberapa kualifikasi akuntan forensik diantaranya yaitu harus kreatif, memiliki rasa ingin tahu, tak menyerah, akal sehat, business sense, dan percaya diri.

Beberapa penelitian yang meneliti tentang akuntan forensik diantaranya yaitu penelitian yang dilakukan oleh Rezaee dan Burton (1997). Hasil penelitiannya menunjukkan bahwa pihak akademisi sendiri memilih untuk mengintegrasikan topik akuntansi forensik ada di program akuntansi, sedangkan pemeriksa kecurangan yang bersertifikat menghendaki pada program yang terpisah. Rezaee (2002) menguji pendapat beberapa lulusan sarjana akuntansi, dan hasilnya menunjukkan bahwa para siswa tersebut percaya bahwa akuntansi forensik adalah pilihan karir yang layak tetapi belum mendapatkan perhatian yang tepat atau serius di perguruan tinggi.

Beberapa penelitian lain yang meneliti tentang perbedaan persepsi tentang keterampilan akuntan forensik diantaranya yaitu Digabriele (2008). Digabriele melakukan investigasi empiris tentang keterampilan yang relevan dengan akuntan forensik. Sembilan keterampilan akuntan forensik tersebut yaitu analisis deduktif, kemampuan berpikir kritis, pemecahan masalah tidak terstruktur, fleksibilitas investigatif, kemampuan analitis, komunikasi oral, komunikasi tertulis, pengetahuan hukum secara spesifik dan ketenangan.

Iprianto (2009) meneliti perbedaan persepsi antara akademisi dengan praktisi akuntan forensik. Hasilnya menyatakan bahwa antara akademisi dengan praktisi mempunyai persepsi yang sama tentang keterampilan akuntan forensik khususnya dalam bidang kemampuan analisis deduktif, keahlian analitik, komunikasi tertulis, pengetahuan tentang hukum, dan bersikap tenang. Namun dalam penelitiannya, Iprianto menyatakan bahwa ada perbedaan persepsi antara akademisi dan praktisi tentang keterampilan akuntan forensik khususnya dalam bidang kemampuan pemikiran kritis, memecahkan masalah tidak terstruktur, fleksibilitas penyidikan,

82

Jurnal Akuntansi Indonesia

Vol. 7 No. 1 Januari 2018 
dan komunikasi lisan. Hasil penelitian Iprianto ini berbeda dengan hasil penelitian sebelumnya, Digabriele (2008) tentang keterampilan akuntan forensik khususnya dalam bidang analisis deduktif, kemampuan analitis, dan pentingnya pengetahuan hukum. Dua literatur pembelajaran yang mendasari penelitian Digabriele adalah aliran akademis yang mempunyai persepsi bahwa materi akuntan forensik berisi tentang pelajaran dan rekomendasi, sedangkan aliran praktisi mempunyai persepsi bahwa keterampilan akuntan forensik lebih dihubungkan dalam prakteknya.

Namun dari beberapa penelitian di atas, belum ada penelitian yang secara khusus mengidentifikasi keterampilan yang relevan dengan akuntan forensik, khususnya dalam sektor publik. Penelitian ini mereplikasi penelitian Digabriele (2008). Perbedaan penelitian ini dengan penelitian sebelumnya yaitu perbedaan sampel. Penelitian ini menganalisis tentang praktisi dan pengguna akuntan forensik di sektor publik sedangkan Digabriele (2008) menganalisis tentang akuntan forensik di sektor swasta. Penelitian ini penting dilakukan mengingat adanya perbedaan fenomena antara peran akuntan forensik di Amerika Serikat dengan peran akuntan forensik di Indonesia. Tuanakota (2010) menyatakan bahwa penerapan audit investigatif (peran akuntan forensik) di Indonesia lebih menonjol di sektor publik dibandingkan dengan penerapannya di sektor swasta. Jadi, akuntan forensik dan audit investigasi di Indonesia lebih dikenal di lingkungan institusi pemerintah. Peran akuntan forensik di sektor publik dilakukan oleh BPK dan BPKP. BPK dan BPKP melakukan peran akuntan forensik sebagai Ahli selaku lembaga negara, bukan pribadi. Pengguna kesaksian ahli dari BPK dan BPKP ini adalah jaksa penuntut umum dan hakim. Lain halnya dengan fenomena Amerika, jasa akuntan forensik lebih banyak dilakukan oleh pihak swasta dan pengguna jasa akuntan forensik pihak swasta ini adalah seorang pengacara atau penasehat hukum (attorney), untuk kepentingan memperoleh pendapat ahli.

Penelitian ini sangat penting dilakukan mengingat penelitian keahlian akuntan forensik sektor publik ini tentunya lebih sesuai apabila digunakan sebagai pedoman kurikulum di Indonesia. Hal itu disebabkan karena kebutuhan akuntan sektor publik di Indonesia memang lebih banyak dibandingkan sektor swasta.

\section{TELAAH PUSTAKA DAN PENGEMBANGAN HIPOTESIS}

\section{Teori Nature dan Teori Nurture}

Tiap individu memang memiliki keunikan tersendiri. Tidak ada satu pun makhluk hidup di dunia ini yang sama persis. Hal itu sesuai dengan teori Nature and Nurture. Berdasarkan teori nature Powell (2010) menyatakan bahwa kecerdasan, kepribadian, agresivitas, dan sexual orientation ditentukan berdasarkan faktor genetic, sedangkan menurut teori nurture, itu semua tidak hanya ditentukan berdasarkan faktor genetic saja tetapi juga dipengaruhi oleh lingkungan (nurture). Jadi faktor lingkungan atau faktor pengaruh dari luar juga mempunyai pengaruh yang besar bagi pembentukan individu. Perbedaan individu inilah yang memungkinkan masingmasing individu memiliki perbedaan persepsi.

Teori lain yang mendukung teori nature and nurture adalah teori konvergensi. Teori konvergensi menyatakan bahwa perkembangan individu akan ditentukan baik oleh faktor yang dibawa sejak lahir (faktor endogen) maupun faktor lingkungan (termasuk pengalaman dan pendidikan) yang merupakan faktor eksogen (Walgito, 1997). Faktor endogen ini meliputi sifat kejasmanian, temperamen dan bakat. Ciri jasmani diantaranya 
meliputi warna kulit, warna rambut, bentuk rambut dan sebagainya. Temperamen sendiri merupakan sifat pembawaan yang erat hubungannya dengan struktur kejasmanian seseorang yaitu berhubungan dengan fungsi fisiologis seperti darah, kelenjar-kelenjar, cairan-cairan lain yang terdapat dalam diri manusia. Walgito (1997) juga menyatakan bahwa bakat bukanlah sesuatu yang telah jadi, yang telah terbentuk pada waktu individu dilahirkan, tetapi baru merupakan potensi-potensi saja. Untuk mengaktualisasikan bakat diperlukan lingkungan yang baik yang mendukung. Dari penjelasan ini terlihat jelas bahwa lingkungan pun mempunyai peran yang sangat penting untuk menunjang faktor endogen itu.

Dengan adanya perasaan, pendidikan dan pengalaman yang berbeda, maka antara praktisi akuntan forensik dengan pengguna jasa akuntan forensik akan mempunyai kecenderungan perbedaan persepsi. Perbedaan persepsi di antara kedua pihak ini perlu diteliti, untuk mengetahui persepsinya tentang keterampilan akuntan forensik di sektor publik. Praktisi akuntan forensik sendiri mempunyai kepentingan akan keterampilan akuntan forensik ketika bekerja di lapangan. Di sisi lain, pengguna akuntan forensik mempunyai kepentingan akan keterampilan akuntan forensik dalam proses sidang pengadilan. Apabila persepsi dari kedua pihak sudah diketahui, diharapkan bisa menjadi masukan bagi pihak akademisi dalam menyusun kurikulum program studi akuntansi forensik di Indonesia.

Akuntansi forensik didefinisikan sebagai investigasi kecurangan, termasuk audit catatan akuntansi untuk membuktikan ada dan tidaknya tindakan kecurangan (Singleton et al., 2006). Dari definisi tersebut, diketahui bahwa seorang akuntan ataupun auditor yang melakukan invetigatif atas suatu kasus, akan dikategorikan sebagai seorang akuntan forensik.

Seperti yang telah dijelaskan sebelumnya, bahwa akuntansi forensik merupakan perpaduan antara ilmu akuntansi, auditing dan hukum. Akuntansi forensik ini berhubungan dengan ilmu hukum, karena profesi akuntan forensik akan berhubungan dengan proses pengadilan. Kesaksian ahli seorang akuntan forensik akan menjadi dasar pembuatan surat dakwaan. Perhitungan kerugian keuangan negara oleh akuntan forensik, akan menjadi dasar pembuatan surat dakwaan.

\section{Pengembangan Hipotesis}

Persepsi praktisi akuntan forensik akan berbeda dengan persepsi pengguna jasa akuntan forensik. Pengguna jasa akuntan forensik (jaksa dan hakim) jelas mempunyai pendidikan yang berbeda. Jaksa dan hakim ini mempunyai latar belakang pendidikan hukum, dan pengalamannya lebih banyak berhubungan dengan proses pengadilan. Mengingat jaksa dan hakim ini hanya membutuhkan jasa akuntan forensik ketika dalam proses pengadilan, tentunya mereka mempunyai persepsi bahwa kemampuan analisis deduktif ini tidak begitu penting. Bagi jaksa dan hakim, seorang akuntan forensik yang baik adalah yang mampu menyampaikan kesaksian ahlinya dengan baik dan mudah dimengerti oleh orang awam. Dari penjelasan di atas, maka dapat dirumuskan:

\section{H1: Pihak praktisi akuntan forensik dan pengguna jasa akuntan forensik mempunyai perbedaan persepsi tentang keterampilan akuntansi forensik dalam bidang analisis deduktif.}

Jurnal Akuntansi Indonesia 
Kemampuan berpikir kritis merupakan kemampuan untuk dapat membedakan mana yang merupakan opini dan mana yang merupakan fakta (Digabriele, 2008). Pengguna jasa akuntan forensik tentunya mempunyai persepsi yang tinggi tentang pentingnya kemampuan berpikir kritis. Hal itu disebabkan karena kemampuan berpikir kritis seorang akuntan forensik sangat berkaitan dengan proses pengadilan. Opini dan fakta harus dibedakan ketika digunakan sebagai bukti di pengadilan. Praktisi akuntan forensik juga mempunyai persepsi yang tinggi tentang pentingnya kemampuan berpikir kritis. Namun, mungkin tidak setinggi praktisi akuntan forensik. Kemampuan berpikir kritis ini juga dibutuhkan seorang akuntan forensik ketika praktek di lapangan. Kemampuan berpikir kritis ini akan membantu seorang akuntan forensik untuk bekerja secara cepat. Kemampuan berpikir kritis ini juga membantu praktisi akuntan forensik ketika bersaksi di pengadilan. Dari penjelasan di atas, maka dapat dirumuskan:

\section{H2: Pihak praktisi akuntan forensik dan pengguna jasa akuntan forensik mempunyai perbedaan persepsi tentang keterampilan akuntansi forensik dalam bidang kemampuan berpikir secara kritis.}

Pihak pengguna jasa akuntan forensik membutuhkan kesaksian ahli akuntan forensik ketika sidang dalam proses pengadilan (litigation). Dengan demikian pengguna jasa akuntan forensik hanya mendengar proses pencarian bukti oleh akuntan forensik. Pengguna jasa akuntan forensik ini tidak melihat dan merasakan sendiri. Dengan demikian, pengguna jasa akuntan forensik akan mempunyai persepsi yang tinggi tentang kemampuan pemecahan masalah tidak terstruktur dalam hubungannya dengan proses pengumpulan bukti. Akan tetapi, persepsi pengguna jasa akuntan forensik ini tentunya tidak setinggi persepsi praktisi, yang mengalami sendiri proses pencarian bukti tersebut. Dari penjelasan di atas, maka dapat dirumuskan:

\section{H3: Pihak praktisi akuntan forensik dan pengguna jasa akuntan forensik mempunyai perbedaan persepsi tentang keterampilan akuntansi forensik dalam bidang pemecahan masalah tidak terstruktur.}

pengalaman dan pendidikan yang berbeda, pengguna jasa akuntan forensik ini akan mempunyai persepsi yang berbeda pula tentang pentingnya fleksibilitas investigatif. Hal itu sesuai dengan pernyataan Matlin (1998) bahwa persepsi merupakan suatu proses yang melibatkan pengetahuan-pengetahuan sebelumnya dalam memperoleh dan menginterpretasikan stimulus yang ditunjukkan oleh indera. Dari penjelasan di atas, maka dapat dirumuskan:

H4: Pihak praktisi akuntan forensik dan pengguna jasa akuntan forensik mempunyai perbedaan persepsi tentang keterampilan akuntansi forensik dalam bidang fleksibilitas investigatif.

Praktisi akuntan forensik juga mempunyai persepsi yang tinggi terhadap kemampuan analitis ini. Dengan dimilikinya kemampuan analitis ini, seorang akuntan forensik akan mampu bekerja secara cepat dan tepat di lapangan. Kemampuan analitis ini lebih berkaitan dengan peran akuntan forensik untuk proses sidang 
pengadilan. Oleh karena itu, pihak pengguna jasa akuntan forensik akan mempunyai persepsi yang lebih tinggi daripada praktisi. Dari penjelasan di atas, maka dapat dirumuskan:

\section{H5: Pihak praktisi akuntan forensik dan pengguna jasa akuntan forensik mempunyai perbedaan persepsi tentang keterampilan akuntansi forensik dalam bidang kemampuan analitis.}

Kemampuan untuk berkomunikasi oral merupakan kemampuan untuk berkomunikasi secara efektif sebagai saksi ahli dan mampu memberikan penjelasan secara umum tentang dasar pendapatnya (Digabriele, 2008). Pengguna jasa akuntan forensik mempunyai persepsi yang sangat tinggi tentang pentingnya kemampuan berkomunikasi oral. Kemampuan berkomunikasi oral seorang akuntan forensik sangat dibutuhkan dalam proses pengadilan. Seorang akuntan forensik dituntut untuk mampu menyampaikan kesaksian ahlinya dalam bahasa yang mudah dimengerti oleh orang awam. Praktisi akuntan forensik juga mempunyai persepsi yang tinggi tentang pentingnya kemampuan komunikasi oral. Akan tetapi, persepsi praktisi akuntan forensik tidak setinggi persepsi pengguna jasa akuntan forensik. Kemampuan komunikasi oral yang dimiliki seorang akuntan forensik, akan memudahkan perannya sebagai saksi ahli di pengadilan. Dari penjelasan di atas, maka dapat dirumuskan:

\section{H6: Pihak praktisi akuntan forensik dan pengguna jasa akuntan forensik mempunyai perbedaan persepsi tentang keterampilan akuntansi forensik dalam bidang komunikasi oral.}

Kemampuan untuk berkomunikasi secara tertulis merupakan kemampuan untuk berkomunikasi secara efektif melalui tulisan dalam bentuk laporan, tabel, grafik dan skedul yang berisi tentang dasar pendapatnya (Digabriele, 2008). Kemampuan berkomunikasi secara tertulis ini berhubungan dengan laporan investigasi akuntan forensik yang digunakan jaksa sebagai acuan pembuatan surat dakwaan. Hakim pun membutuhkan laporan investigasi akuntan forensik sebagai bukti kesaksian ahli. Dengan demikian, pengguna jasa akuntan forensik (jaksa dan hakim) tentunya mempunyai persepsi yang sangat tinggi tentang pentingnya kemampuan berkomunikasi secara tertulis. Begitu juga dengan persepsi dari praktisi akuntan forensik. Praktisi akuntan forensik sangat membutuhkan kemampuan komunikasi secara tertulis ini sehubungan dengan perannya sebagai saksi ahli dalam proses pengadilan. Dari penjelasan di atas, maka dapat dirumuskan:

\section{H7: Pihak praktisi akuntan forensik dan pengguna jasa akuntan forensik mempunyai perbedaan persepsi tentang keterampilan akuntansi forensik dalam bidang komunikasi tertulis.}

Pengetahuan hukum secara spesifik diartikan sebagai kemampuan untuk mengetahui dasar-dasar proses hukum dan isu hukum, termasuk aturan tentang bukti (Digabriele, 2008). Tingginya pengetahuan hukum bagi seorang akuntan forensik akan sangat bermanfaat bagi pihak pengguna jasa akuntan forensik. Hal ini akan mendukung peran akuntan forensik sebagai saksi ahli dalam proses pengadilan. Dengan demikian, pengguna jasa akuntan forensik mempunyai persepsi yang sangat tinggi tentang pentingnya pengetahuan hukum. 
Praktisi akuntan forensik juga mempunyai persepsi yang tinggi tentang pentingnya pengetahuan hukum. Hal ini juga akan memudahkan perannya sebagai saksi ahli dalam pengadilan. Akan tetapi, persepsi praktisi akuntan forensik tentunya tidak setinggi pihak pengguna jasa akuntan forensik. Dari penjelasan di atas, maka dapat dirumuskan:

\section{H8: Pihak praktisi akuntan forensik dan pengguna jasa akuntan forensik mempunyai perbedaan persepsi tentang keterampilan akuntansi forensik dalam bidang pengetahuan hukum secara spesifik.}

Ketenangan diartikan sebagai kemampuan untuk tetap bersikap tenang walaupun dalam situasi tertekan (Digabriele, 2008). Ketenangan ini sangat dibutuhkan seorang akuntan forensik ketika berperan sebagai saksi ahli dalam persidangan. Strategi penasehat hukum (pengacara) adalah menyerang dan melemahkan keterangan ahli yang diajukan penuntut umum (Tuanakota, 2009). Dalam proses pengadilan, pengacara tentunya berusaha membuat akuntan forensik stres dan tertekan. Hal itu dilakukan agar akuntan forensik menjadi gugup, bingung dan tidak mampu menjawab segala pertanyaan dengan jelas. Dengan demikian, ketenangan seorang akuntan forensik sangatlah penting bagi pihak pengguna jasa akuntan forensik. Praktisi akuntan forensik pun mempunyai persepsi yang tinggi tentang pentingnya ketenangan. Hal itu berkaitan dengan pengalamannya ketika berperan sebagai saksi ahli dalam proses pengadilan. Akan tetapi, persepsi praktisi tentang pentingnya ketenangan tentunya tidak setinggi pihak pengguna jasa akuntan forensik. Dari penjelasan di atas, maka dapat dirumuskan:

H9: Pihak praktisi akuntan forensik dan pengguna jasa akuntan forensik mempunyai perbedaan persepsi tentang keterampilan akuntansi forensik dalam bidang ketenangan.

\section{METODE PENELITIAN}

Penelitian ini merupakan penelitian empirik yang menganalisis perbedaan persepsi antara praktisi akuntan forensik dengan pengguna jasa akuntan forensik tentang keterampilan yang relevan dengan akuntan forensik. Penelitian ini merupakan penelitian survei (survey research) yang berupa pengujian hipotesis. Penelitian ini menggunakan kuesioner untuk mengetahui persepsi dari praktisi akuntan forensik dengan pengguna jasa akuntan forensik, tentang keterampilan yang relevan dengan akuntan forensik dalam bidang analisis deduktif, pemikiran kritis, pemecahan masalah tidak terstruktur, fleksibilitas investigatif, kemampuan analisis, komunikasi oral, komunikasi tertulis, pengetahuan hukum secara spesifik, dan ketenangan. Penyebaran kuesioner akan diberikan langsung kepada pihak yang bersangkutan.

Populasi dalam penelitian ini adalah praktisi BPK, BPKP, jaksa dan hakim di Semarang dan Yogyakarta. Praktisi BPK dan BPKP dipilih sebagai pihak praktisi akuntan forensik, yang sudah terbiasa bekerja dalam audit investigasi sektor publik. Hal itu sesuai dengan pernyataan Tuanakota (2010) bahwa peran penting para akuntan forensik di Indonesia terlihat pada BPK dan BPKP. Jaksa dan hakim merupakan pihak yang membutuhkan kesaksian ahli BPK ataupun BPKP di persidangan. Dengan demikian, jaksa dan hakim adalah pihak pengguna jasa akuntan forensik. 
Tehnik pengambilan sampel dalam penelitian ini menggunakan metode Purposive Sampling, khususnya judgement sampling. Judgement sampling merupakan tehnik pengambilan sampel dengan menggunakan pertimbangan tertentuyang disesuaikan dengan tujuan penelitian atau masalah penelitian yang dikembangkan (Ferdinand, 2006).

Variabel yang digunakan dalam penelitian ini diantaranya yaitu analisis deduktif, kemampuan berpikir kritis, pemecahan masalah tidak terstruktur, fleksibilitas investigatif, kemampuan analitis, komunikasi oral, komunikasi tertulis, pengetahuan hukum secara spesifik, dan ketenangan. Adapun penjelasan definisi operasional variabel dan pengukurannya dapat dilihat berikut ini (Digabriele, 2008):

1. Analisis Deduktif

Analisis Deduktif didefinisikan sebagai kemampuan untuk mengenali maupun menyadari adanya ketidaksesuaian antara laporan keuangan yang disajikan dengan standar yang telah ditentukan.

2. Kemampuan Berpikir Kritis

Kemampuan berpikir kritis didefinisikan sebagai kemampuan untuk dapat membedakan mana yang merupakan opini dan mana yang merupakan fakta.

3. Pemecahan Masalah Tidak Terstruktur

Pemecahan masalah tidak terstruktur didefinisikan sebagai kemampuan dalam segala situasi apapun, untuk merencanakan sebuah pemecahan untuk masalah yang tidak tersusun dengan baik, acak-acakan.

4. Fleksibilitas Investigatif

Fleksibilitas investigatif didefinisikan sebagai kemampuan untuk tidak selalu bekerja sesuai dengan prosedur audit yang sudah distandarisasi, melainkan memeriksa secara situasional, tidak harus selalu sesuai dengan standar prosedur audit yang ada.

5. Kemampuan Analitis

Kemampuan analitis didefinisikan sebagai kemampuan untuk menentukan tentang apa saja yang seharusnya ada, daripada apa yang sudah ada.

6. Komunikasi Oral

Komunikasi Oral didefinisikan sebagai kemampuan untuk berkomunikasi secara efektif sebagai saksi ahli dan mampu memberikan penjelasan secara umum tentang dasar pendapatnya.

7. Komunikasi Tertulis

Komunikasi tertulis didefinisikan sebagai kemampuan untuk berkomunikasi secara efektif melalui tulisan dalam bentuk laporan, tabel, grafik dan skedul yang berisi tentang dasar pendapatnya.

8. Pengetahuan Hukum secara Spesifik

Pengetahuan hukum secara spesifik didefinisikan sebagai kemampuan untuk mengetahui dasar-dasar proses hukum dan isu hukum, termasuk aturan tentang bukti.

9. Ketenangan

Ketenangan didefinisikan sebagai kemampuan untuk tetap bersikap tenang walaupun dalam situasi tertekan.

Dari kesembilan variabel di atas menggunakan skala pengukuran Likert yaitu $1=$ Tidak Penting Sekali, 
$2=$ Tidak Penting, $3=$ Netral, $4=$ Penting, dan $5=$ Penting Sekali. Analisis statistik yang digunakan dalam penelitian ini: statistik deskriptif digunakan untuk memberikan gambaran mengenai variabel-variabel penelitian, uji kualitas data yang terdiri dari uji validitas dan uji reliabilitas, uji normalitas. Screening terhadap normalitas data merupakan langkah awal yang harus dilakukan untuk setiap analisis multivariate, khususnya jika tujuannya adalah inferensi (Ghozali, 2007). Untuk menguji normalitas data, penelitian ini menggunakan uji statistik Kolmogorov - Smirnov.

Penelitian ini juga menggunakan uji One Way Anova dengan tingkat signifikansi 0,05. Uji One Way Anova dipilih karena penelitian ini melakukan uji beda antara lebih dari 2 pihak yaitu persepsi antara praktisi akuntan forensik (terdiri dari BPK dan BPKP) dengan pengguna jasa akuntan forensik (terdiri dari jaksa dan hakim).

\section{HASIL PENELITIAN DAN PEMBAHASAN}

Dari tabel 1 di atas dapat diketahui bahwa ada tujuh hipotesis yang diterima dan ada dua hipotesis yang ditolak. Ada beberapa variabel yang konsisten dengan penelitian sebelumnya, digabrielle (2008). Akan tetapi ada juga yang berbeda dengan hasil penelitian sebelumnya. Variabel yang konsisten dengan penelitian sebelumnya adalah variabel analisis deduktif, kemampuan berpikir kritis, pemecahan masalah tidak terstruktur, kemampuan analitis, pengetahuan hukum dan komunikasi tertulis. Adapun variabel yang berbeda dengan penelitian sebelumnya adalah fleksibilitas investigatif, komunikasi oral dan ketenangan.

Hasil penelitian ini membuktikan bahwa praktisi akuntan forensik dan pengguna jasa akuntan forensik mempunyai perbedaan persepsi tentang keterampilan akuntansi forensik dalam bidang analisis deduktif. Hal itu terbukti dari hasil uji anova dengan nilai signifikansi sebesar $0.0000<0.05$. Berdasarkan hasil uji post hoc diketahui bahwa persepsi praktisi akuntan forensik (BPK dan BPKP) tentang kemampuan deduktif lebih tinggi apabila dibandingkan dengan pengguna jasa akuntan forensik (jaksa dan hakim). Hal ini terlihat dari hasil mean difference, baik BPK maupun BPKP mempunyai nilai positif terhadap jaksa dan hakim. Bukti ini memperkuat dugaan bahwa BPK dan BPKP memiliki latar pendidikan yang berhubungan dengan hukum akuntansi sehingga memiliki persepsi yang lebih tinggi apabila dibandingkan dengan jaksa dan hakim.

Pada pengujian variabel kemampuan berfikir kritis diketahui bahwa terdapat perbedaan persepsi tentang ketrampilan akuntansi forensik dalam bidang kemampuan berpikir secara kritis. Hal ini terbukti dari nilai signifikansi sebesar $0.000<0.05$. Dari hasil uji deskriptif dan post hoc diketahui bahwa praktisi akuntan forensik (BPK dan BPKP) memiliki persepsi tentang kemampuan berpikir kritis yang lebih rendah dibandingkan dengan pengguna jasa akuntan forensik (jaksa dan hakim). Hal ini terlihat dari hasil mean difference, baik BPK maupun BPKP mempunyai nilai negatif terhadap jaksa dan hakim. Hasil ini mendukung dugaan bahwa pengguna jasa akuntan forensik mempunyai persepsi yang lebih tinggi dalam hal kemampuan berfikir kritis karena kemampuan ini sangat penting bagi akuntan forensik, khususnya dalam proses pengadilan.

Pengujian variabel pemecahan masalah terstruktur membuktikan bahwa pihak praktisi akuntan forensik dan pengguna jasa akuntan forensik terbukti mempunyai perbedaan persepsi tentang keterampilan akuntansi forensik dalam bidang pemecahan masalah tidak terstruktur. Hal ini terbukti dari nilai signifikansi sebesar $0.000<0.05$. Dari hasil analisis deskriptif tentang kemampuan pemecahan masalah tidak terstruktur diketahui 
bahwa BPK dan BPKP memiliki persepsi yang lebih tinggi apabila dibandingkan dengan jaksa dan hakim. Hal ini terlihat dari hasil mean difference, baik BPK maupun BPKP mempunyai nilai positif terhadap jaksa dan hakim Hasil ini mendukung dugaan bahwa kemampuan pemecahan masalah tidak terstruktur dibutuhkan akuntan forensik ketika bekerja di lapangan. Praktisi akuntan forensik tentunya mempunyai persepsi sangat tinggi tentang pentingnya kemampuan pemecahan masalah tidak terstruktur ini. Hal itu disebabkan karena pengalaman praktisi akuntan forensik lebih banyak di lapangan.

Penelitian ini tidak membuktikan bahwa pihak praktisi akuntan forensik dan pengguna jasa akuntan forensik mempunyai perbedaan persepsi tentang keterampilan akuntansi forensik dalam bidang fleksibilitas investigatif. Hal ini terbukti dari nilai signifikansi sebesar $0.211>0.05$. Berdasarkan hasil deskriptif diketahui bahwa fleksibilitas investigasi keempat kelompok akuntan adalah relatif sama yaitu masuk dalam kriteria tinggi. Hasil ini tidak mendukung dugaan bahwa praktisi akuntan forensik mempunyai persepsi yang lebih tinggi tentang pentingnya kemampuan fleksibilitas investigatif. Para pengguna jasa akuntan forensik memiliki persepsi kemampuan fleksibilitas investigatif yang tinggi karena kemampuan fleksibilitas investigatif sangat diperlukan dalam proses peradilan. Kemampuan untuk melakukan pemeriksaan secara situasional dan tidak sesuai dengan standar prosedur audit terbukti tidak berbeda antara akuntan praktisi dan akuntan pengguna jasa. Hal ini disebabkan kemampuan untuk melakukan improvisasi adalah sebuah kemampuan alami (nature), sehingga aspek-aspek didik (nurture) yang membentuk karakter akuntan praktisi dan pengguna jasa tidak dapat menjelaskan fleksibilitas investigatif.

Variabel kemampuan analitis terbukti berbeda diantara kelompok praktisi akuntan forensik dan pengguna jasa akuntan forensik. Hal ini terbukti dari nilai signifikansi sebesar $0.000<0.05$. Namun demikian hasil uji deskriptif diketahui bahwa jaksa dan hakim memiliki kemampuan analitis yang lebih baik dibandingkan dengna BPK dan BPKP. Kemampuan analitis jaksa dan hakim terbukti tinggi, sedangkan kemampuan analitis BPK dan BPKP terbukti sedang. Hasil ini mendukung dugaan bahwa, sehubungan dengan perannya sebagai saksi ahli di pengadilan, kemampuan analitis seorang akuntan forensik tentu sangatlah penting untuk dimiliki jaksa dan hakim.

Pada pengujian variabel kemampuan komunikasi oral diketahui bahwa pihak praktisi akuntan forensik dan pengguna jasa akuntan forensik mempunyai perbedaan persepsi tentang keterampilan akuntansi forensik dalam bidang komunikasi oral. Hal ini terbukti dari nilai signifikansi sebesar $0.000<0.05$. Dari hasil deskriptif diketahui bahwa jaksa dan hakim memiliki kemampuan oral yang lebih tinggi dibandingkan dengan kemampuan oral BPK dan BPKP. Tingginya kemampuan komunikasi oral jaksa dan hakim berkaitan dengan tuntutan bahwa pekerjaan hakim dan jaksa berkaitan dengan kemampuan ini sangat diperlukan dalam proses peradilan. Hasil ini mendukung dugaan bahwa persepsi praktisi akuntan forensik tidak setinggi persepsi pengguna jasa akuntan forensik, karena kemampuan komunikasi oral yang dimiliki seorang akuntan forensik, sangat diperlukan perannya sebagai saksi ahli di pengadilan.

Pada pengujian variabel komunikasi tertulis, pihak praktisi akuntan forensik dan pengguna jasa akuntan forensik tidak terbukti mempunyai perbedaan persepsi tentang keterampilan akuntansi forensik dalam bidang komunikasi tertulis. Hal ini terbukti dari nilai signifikansi sebesar $0.04<0.05$. Dari uji one way ANOVA hasilnya 
signifikan. Akan tetapi, setelah dilakukan uji Tukey, terbukti BPK hanya signifikan terhadap jaksa. BPK terbukti tidak signifikan terhadap hakim. Pihak pengguna jasa akuntan forensik diwakili oleh dua pihak yaitu jaksa dan hakim. Oleh karena itu, hipotesis tujuh tetap dinyatakan ditolak. Hasil analisis deskriptif membuktikan bahwa kemampuan tertulis BPK, BPKP dan hakim masuk kategori sedang, sedangkan kemampuan jaksa masuk dalam kategori tinggi. Tidak adanya kemampuan komunikasi tertulis membuktikan bahwa praktisi akuntan forensik maupun pengguna jasa akuntan forensik sama-sama memerlukan kemampuan komunikasi tertulis dalam bidangnya.

Selanjutnya penelitian ini membuktikan bahwa pihak praktisi akuntan forensik dan pengguna jasa akuntan forensik terbukti mempunyai perbedaan persepsi tentang keterampilan akuntansi forensik dalam bidang pengetahuan hukum secara spesifik. Hal ini terbukti dari nilai signifikansi sebesar $0.000<0.05$. Berdasarkan uji Tukey diketahui bahwa jaksa dan hakim lebih tinggi dalam hal pentingnya pengetahuan hukum dibandingkan dengan BPK dan BPKP, hal ini berkaitan dengan latar belakang pendidikan dan profesi jaksa dan hakim yang memang terfokus pada hal - hal yang berkaitan dengan hukum dibandingkan dengan BPK dan BPKP. Hal ini terbukti dari nilai mean difference hasil uji Tukey untuk kelompok BPK dan BPKP terhadap jaksa maupun hakim, sama-sama bernilai negatif semua.

Pada variabel terakhir, diketahui bahwa pihak praktisi akuntan forensik dan pengguna jasa akuntan forensik terbukti mempunyai perbedaan persepsi tentang keterampilan akuntansi forensik dalam bidang ketenangan. Hal ini terbukti dari nilai signifikansi sebesar $0.000<0.05$. Persepsi hakim dan jaksa tentang ketenangan terbukti lebih tinggi dibandingkan dengan BPK dan BPKP. Hal ini terbukti dari nilai mean difference hasil uji Tukey untuk kelompok BPK dan BPKP terhadap jaksa maupun hakim, sama-sama bernilai negatif semua. Hal ini terjadi karena dalam proses pengadilan, pengacara berusaha membuat akuntan forensik stres dan tertekan. Hal itu dilakukan agar akuntan forensik menjadi gugup, bingung dan tidak mampu menjawab segala pertanyaan dengan jelas. Kebiasaan tekanan terhadap jaksa dan hakim menjadikan jaksa dan hakim lebih terbiasa dalam tekanan sehingga memiliki kemampuan untuk lebih tenang dibandingkan dengan BPK dan BPKP.

\section{KESIMPULAN}

Hasil penelitian ini menyatakan bahwa antara praktisi dengan pengguna jasa akuntan forensik mempunyai perbedaan persepsi dalam keahlian akuntan forensik khususnya dalam bidang analisis deduktif, kemampuan berpikir kritis, pemecahan masalah tidak terstruktur, kemampuan analitis, komunikasi oral, pengetahuan tentang hukum dan ketenangan. Akan tetapi, antara praktisi dengan pengguna jasa akuntan forensik mempunyai persepsi yang sama dalam keahlian fleksibilitas investigatif, dan komunikasi tertulis .

Riset ini membuktikan adanya perbedaan kemampuan analisis deduktif, pemikiran kritis, pemecahan masalah tidak terstruktur, kemampuan analisis, kemampuan oral, pengetahuan hukum dan ketenangan. Bagi lembaga-lembaga akademi disarankan untuk memperhatikan heteroginitas peserta didik akuntan forensik dengan memberikan pendidikan tambahan bagi akuntan praktisi maupun pengguna jasa akuntan sesuai dengan temuan riset. 
Riset hanya dilakukan di dua Kota besar di Jawa Tengah, bagi penelitian yang akan datang disarankan untuk mempertimbangkan data non persepsi mengenai variabel - variabel tersebut, sehingga diperoleh hasil riset yang lebih objektif

Jurnal Akuntansi Indonesia 


\section{DAFTAR PUSTAKA}

Digabriele A James. (2008). An Empirical Investigation of the Relevant Skills of Forensic Accountants. Journal of Education for Business. Heldref Publication.

Edratna. (2009). Apa, Bagaimana dan Kapan Akuntansi Forensik digunakan? http://edratna.wordpress. com/2009/04/27/apa-bagaimana-dan-kapan-akuntansi-forensik-digunakan/ diakses tanggal 8 November 2010

Ferdinand A. (2006), Metode Penulisan Manajemen Untuk Penulisan Skripsi, Tesis dan Disertasi IImu Manajemen, Semarang

Ghozali, Imam (2007), Aplikasi Analisis Multivariate dengan Program SPSS, Semarang : Badan Penerbit Universitas Diponegoro

Iprianto. (2009), Persepsi Akademisi dan Praktisi Akuntansi Terhadap Keahlian Akuntan Forensik, Tesis, Magister Akuntansi Universitas Diponegoro

Powell K. Nature vs Nurture. Are We Really Born That Way?http://genealogy.about.com/cs/ geneticgenealogy/a/nature nurture.htm diakses tanggal 9 November 2010.

Ramaswamy, V. (2005). Corporate Governance and The Forensic Accountant. CPA Journal. 75. 68-70.

Rezaee, Z., \& Burton, E. J. (1997). Forensic Accounting Education: Insights from Academicians and Certified Fraud Examiner Practitioners. Managerial Auditing Journal.

Rezaee, Z., Crumbely, L. D., \& Elmore, R. C. (2006). Forensic Accounting Education: A Survey of Academicians and Practitioners. Advances in Accounting Education.

Tuanakota, M. T. (2010). Akuntansi Forensik dan Audit Investigatif. Edisi 2. Jakarta : Salemba Empat.

Tuanakota, M. T. (2009). Menghitung Kerugian Keuangan Negara. Jakarta : Salemba Empat. 


\section{Lampiran:}

Tabel 1.

Ringkasan Hasil Uji Hipotesis

\begin{tabular}{|c|l|c|}
\hline Hipotesis & \multicolumn{1}{|c|}{ Variabel di Dalam Hipotesis } & Hasil Penelitian \\
\hline 1. & Analisis Deduktif & Diterima \\
2. & Kemampuan Berpikir Kritis & Diterima \\
3. & Pemecahan Masalah Tidak Terstruktur & Diterima \\
4. & Fleksibilitas Investigatif & Ditolak \\
5. & Kemampuan Analitis & Diterima \\
6. & Komunikasi Oral & Diterima \\
7. & Komunikasi Tertulis & Ditolak \\
8. & Pengetahuan Tentang Hukum & Diterima \\
9. & Ketenangan & Diterima \\
\hline
\end{tabular}

Jurnal Akuntansi Indonesia 